\begin{tabular}{|l|l|l||}
\hline \multicolumn{2}{|c|}{ PublisherInfo } \\
\hline \hline PublisherName & $:$ & BioMed Central \\
\hline \hline PublisherLocation & $:$ & London \\
\hline \hline PublisherImprintName & $:$ & BioMed Central \\
\hline \hline
\end{tabular}

\title{
Divine DNA repair
}

\begin{tabular}{|l|l|l||}
\hline \multicolumn{2}{|c|}{ ArticleInfo } \\
\hline \hline ArticleID & $:$ & 4433 \\
\hline \hline ArticleDOI & $:$ & $10.1186 /$ gb-spotlight-20020328-01 \\
\hline \hline ArticleCitationID & $:$ & spotlight-20020328-01 \\
\hline \hline ArticleSequenceNumber & $:$ & 99 \\
\hline \hline ArticleCategory & $:$ & Research news \\
\hline ArticleFirstPage & $:$ & 1 \\
\hline \hline ArticleLastPage & $:$ & 2 \\
\hline \hline & & RegistrationDate : 2002-3-28 \\
\hline ArticleHistory & $:$ & OnlineDate \\
\hline \hline ArticleCopyright & $:$ & BioMed Central Ltd2002-3-28 \\
\hline \hline ArticleGrants & $:$ & \\
\hline \hline ArticleContext & $:$ & 130593311 \\
\hline \hline
\end{tabular}




\section{Tudor Toma}

Email: t.toma@ic.ac.uk

Defects in the human Artemis protein result in hypersensitivity to agents that induce DNA doublestrand breaks and the absence of B and T lymphocytes - often referred to as radiosensitive severe combined immune deficiency (RS-SCID) - but the mechanisms underlying these defects remain unclear. In the March 22 Cell, Yunmei Ma and colleagues from Norris Comprehensive Cancer Center, Los Angeles, show that the Artemis protein (named after the Greek goddess for the protection of children) cuts away the damaged parts of the DNA so that the strands can be joined together again.

Ma et al. found that purified Artemis protein alone has single-strand-specific 5'-to-3' exonuclease activity. In addition, Artemis forms a complex with the $469 \mathrm{kDa}$ DNA-dependent protein kinase (DNAPKcs) in the absence of DNA. DNA-PKcs phosphorylates Artemis, and Artemis acquires endonucleolytic activity on 5' and 3' overhangs, as well as hairpins (Cell 2002, 108:781-794).

"What we're going to do next," said Yunmei Ma, "is try to screen for drugs that inhibit Artemis, because this might be useful from a cancer therapy standpoint. If we could just give a pulse of drug inhibitor for a while, we might be able to focus the effects of radiation therapy, for instance, by not allowing the cancer cells to repair themselves after being hit with the radiation."

\section{References}

1. Ma Y, Pannicke U, Schwarz K, Lieber MR: Hairpin opening and overhang processing by an Artemis/ DNA-dependent protein kinase complex in nonhomologous end joining and $\mathrm{V}(\mathrm{D}) \mathrm{J}$ recombination. Cell 2002, 108:781-794., [http://www.cell.com]

2. USC/Norris Comprehensive Cancer Center, [http://ccnt.hsc.usc.edu/] 